\title{
The patient's journey: living with psoriasis
}

\section{THE PATIENT'S PERSPECTIVE}

\section{Diagnosis and early treatment}

I first saw a doctor with scabs on my scalp in 1951 when I was 23 years old. He sent me to Addenbrookes Hospital in Cambridge where a diagnosis of psoriasis was confirmed and I was provided with an ointment based on coal tar and a mercury salt. Over the 58 years since then I have never been clear from psoriasis lesions; unlike my cousin and an aunt (long dead) who had periods of being clear of all symptoms, interspersed with times when they were covered from head to foot.

During the next few years the patches of scabs spread: first to around my navel and then slowly to the whole of my body. In the early 1960s Betnovate ${ }^{\circledR}$ cream arrived on the scene, and initially this ointment appeared to be a miracle cure, but soon more drastic action was needed.

\section{The middle years}

In the mid-60s and early 1970s I became arthritic. The joints affected were the hands and feet, knees, shoulders - almost everywhere! The arthritis was treated with butazolidin; a wonder drug in that it reduced inflammation and enabled me to continue working as a teacher. (It seems ridiculous, but at one stage I could not raise my hand above the shoulder, which made it very difficult to write on a blackboard!) The only problem with butazolidin (a drug now banned even for racehorses) was that I developed duodenal ulcers, and walked around with digestive biscuits and little pots of milk. By this time the scabs on my skin were being treated by smothering myself in potent steroid cream and encasing myself from head to toes in plastic bags, leaving them on for 36 hours, and then being free from them for a further 36 hours. (I rustled as I moved, and plastic showed above my collar, and at my wrists. Amazingly the boys that I was teaching took no notice whatsoever.) As my arthritis got steadily worse, in the early 1970s it was decided to try gold injections. Within a year I was completely clear from arthritis, with few deformed joints to show for it; a thumb and some toes. Whether the arthritis burnt itself out of its own accord, or whether the gold injections did the trick is anyone's guess. At about this time, Zantac $^{\circledR}$ arrived, and my ulcer pains vanished. Life was looking up. At this stage various other treatments were then tried for my psoriasis. PUVA (Psoralen Ultra VioletA treatment) was started, but when I realised that I was expected to drive to Leicester (20 miles away) 5 days a week for 3 months, I gave it up. During this period, I was also subjected to the dreaded dithranol. My underclothes and shirts all turned red, as did my towels. Even the grouting of the shower turned red. Then, while being daubed with the stuff in hospital my skin decided that it had had enough. I was effectively burnt all over, and was hospitalised and injected with ACTH. Dustpans full of big scabs fell of me, but I survived, and reverted to my Betnovate and plastic bags.

\section{Newer treatments}

In the 1980s I finally got away from the plastic bags when I began taking methotrexate. This was still combined with an ointment, and I was then also using a mercury vapour UV lamp every day. This regime worked pretty well, even if it was rather time-consuming; apart from the day of the dosage of methotrexate, when I had a headache. After 5 years of this, my dermatologist insisted that I had a liver biopsy before continuing. All was OK but when, after a further 5 years, he wanted a further biopsy, my (late) wife would not allow it, having read of a man who had bled to death in a Peterborough hospital.

So then I started on Tigason, about 14 years ago. Getting the dosage right was a bit tricky, but a good, concerned doctor at Leicester Royal Infirmary saw me every fortnight until he got the dosage right. Too little and it didn't work: too much and my skin felt hot and tender. A few years later, Tigason was replaced with Neotigason ${ }^{\circledast}$, or acitretin, and I have remained on it ever since. I take $30 \mathrm{mg}$ a day, and still use an ointment based on coal tar and Betnovate $^{\circledR}$, but a small pot of this lasts months. Acitretin has transformed my life. I don't itch, I don't drop scabs all over the place, I don't think about my psoriasis except every 6 months when I have a blood test (which never varies) and have to go to the infirmary to get another batch of pills.

\section{Henry Pickering}

DOI: 10.3399/bjgp10X483355 